\title{
定荷重・SSRT・CSRT法による 高強度鋼の丸棒試験片を用いた水素脆化評価の比較
}

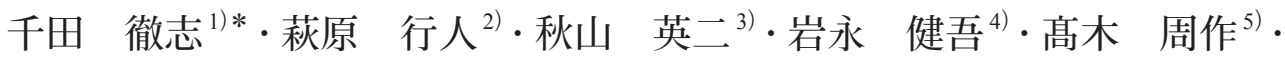 \\ 大石 裕之 $^{6)}$. 早川 正夫 ${ }^{3)} \cdot$ 平上 大輔 $^{1)} \cdot$ 樽井 敏三 ${ }^{7)}$ \\ Comparison of Constant Load, SSRT and CSRT Methods \\ for Hydrogen Embrittlement Evaluation Using Round Bar Specimens of High Strength Steels \\ Tetsushi Chida, Yukito Hagihara, Eiji Akiyama, Kengo Iwanaga, Shusaku TaKagi, \\ Hiroyuki Ohishi, Masao Hayakawa, Daisuke Hirakami and Toshimi Tarui
}

Synopsis : Resistance to hydrogen embrittlement of low alloy steels was evaluated based on their critical hydrogen content and critical stress. Constant load test, Slow Strain Rate Technique (SSRT) and Conventional Strain Rate Technique (CSRT) were carried out using JIS-SCM435 and Vadded steels in six laboratories. It was confirmed that the same test results were obtained in different laboratories under the same test conditions. Furthermore, the relationships between the diffusible hydrogen content and nominal fracture stress obtained by means of CLT and by SSRT were similar to each other. In SSRT and CSRT, fracture surfaces showed Quasi-cleavage mode under small hydrogen content, while they showed Inter-granular fracture under large hydrogen content. In order to compare the three methods considering the concentration of hydrogen in stress field, locally accumulated hydrogen content under the same fracture stress was calculated. The order of the locally accumulated hydrogen content at a given fracture stress is as follows; SSRT $<$ CLT $<$ CSRT in JIS-SCM435, and CSRT $<$ CLT $\fallingdotseq$ SSRT in V-added steels. The difference of the evaluation results for JIS-SCM435 is presumably attributed to the dependence of the interaction between hydrogen and dislocations on the strain rate.

Key words : hydrogen; hydrogen embrittlement; delayed fracture; constant load test; SSRT; CSRT; high strength steel.

\section{1. 緒言}

構造物の軽量化，サイズ低減を目指し，TS1000 MPaを 超える超高強度鋼の適用検討事例が増加している。TS1000 $\mathrm{MPa}$ 超級鋼は, 大気腐食環境で鋼材中に侵入する微量な水 素量でも遅れ破壊と呼ばれる水素脆化 ${ }^{1)}$ が発生する可能 性がある。TS1000 MPa超級鋼を安全かつ効率的に使用す るためには，遅れ破壊が発生するか否かを鋼材使用前に評 価，予測することが重要となる。遅れ破壊の発生可能性を 判断するためには，鋼材の水素に対する抵抗力と使用中の 水素侵入特性を評価することが重要である。これらの評価 には種々の考え方や手法がある。例えば，Yamasakiらは， Troiano らが提唱した鋼材が破壊しない最大の拡散性水素 量 (限界拡散性水素量 $\left.\mathrm{H}_{\mathrm{C}}\right)^{2)}$ の概念を利用し, 限界拡散性 水素量が鋼材使用中に鋼材に侵入する拡散性水素量（侵入
水素量 $\mathrm{H}_{\mathrm{E}}$ ）よりも多い条件では遅れ破壊は発生しない，と する評価を提案している ${ }^{3,4)}$ 。また, Kushidaらは，使用環境 に打ける試験材の水素透過係数を求め, その条件での水素 チャージ下にて破断応力を求めることで耐遅れ破壊発生を 評価している ${ }^{5)}$ 。本報告は前者の評価方法に着目し，限界 拡散性水素量と侵入水素量の二つの因子のうち, 鋼材の水 素に対する抵抗力を示す限界拡散性水素量の評価手法に関 して検討したものである。

限界拡散性水素量を求める手法は, 一般的には定荷 重試験 (CLT, Constant Load Test) ${ }^{2-4)}$, 低ひずみ速度法 (SSRT, Slow Strain Rate Technique) ${ }^{6-12)}$, 通常速度法 (CSRT, Conventional Strain Rate Technique) ${ }^{13-16)}$ ，4点曲げ法 (4 Point Bending method $)^{17)}$ があげられる。これらの評価法の妥当性 を検証する研究やこれらの評価法を用いた鋼材の特性評価 は種々行われているが，それぞれの手法により得られる限

平成26年3月31日受付＼cjkstart平成26年7月22日受理（Received on Mar. 31, 2014 ; Accepted on Jul. 22, 2014)

1）新日鐵住金 (株) 技術開発本部 (Steel Research Laboratories, Nippon Steel \& Sumitomo Metal Corporation, 20-1 Shintomi Futtsu Chiba 293-8511)

2) 元 上智大学 (Former, Sophia University)

3) (独) 物質 ·材料研究機構 (National Institute for Materials Science)

4）高周波熱錬 (株)（Neturen Co., Ltd.)

5）JFEスチール (株) スチール研究所 (Steel Research Laboratory, JFE Steel Corporation)

6）三菱製鋼（株）（Mitsubishi Steel Mfg. Co., Ltd.)

7）日鉄住金テクノロジー (株) (Nippon Steel \& Sumikin Technology Co., Ltd.)

* Corresponding author : E-mail : chida.m27.tetsushi@jp.nssmc.com

DOI : http://dx.doi.org/10.2355/tetsutohagane.100.1298 
界拡散性水素量や水素脆化破壊限界応力の差異は不明であ る。そこで, 本研究では, 種々の評価法で得られる限界拡 散性水素量や水素脆化破壊限界応力の差異を明確にする ことを目的として，同一材料を用いて定荷重試験, SSRT, CSRTにより求められた水素脆化破壊限界の比較を行っ た。

\section{2. 実験方法}

\section{$2 \cdot 1$ 供試材および試験片形状}

供試材は高力ボルトの素材として一般的に使用されてい るSCM435 および，近年耐遅れ破壊性に優れる鋼材として 開発されている微細析出物による水素トラップサイトを利 用した鋼 ${ }^{3,5)}$ の一例としてV添加鋼を用いた。成分詳細は Table 1 に示す。

SCM435鋼は, Table 1 に示す組成の実機鋼塊を直径 10 $\mathrm{mm}$ まで伸線加工を行った後に高周波熱処理装置により Fig.1に示す熱処理を行った。Table 2 に平行部径 $10 \mathrm{~mm}$, ゲージ長 $100 \mathrm{~mm}$ で引張試験を行って得られた特性を示 す。この供試材を $\mathrm{S} 11$ 鋼とする。

一方, V 添加鋼は, Table 1 に示す組成の試験室真空溶解 鋼を直径 $16 \mathrm{~mm}$ まで鍛造後, $920{ }^{\circ} \mathrm{C} て ゙ 60 \mathrm{~min}$ 加熱し, 空冷 する焼ならし処理を行った。その後，Fig.2に示す熱処理を
行った。 $150{ }^{\circ} \mathrm{C} て ゙ 30 \mathrm{~min}$ 加熱した仮戻し処理は, 焼入れ後 から焼戻し処理までの間に数日を要したため, その間の割 れ発生の危険性を極力低くする目的で，焼入れ直後に 150 ${ }^{\circ} \mathrm{C}$ で30 min 加熱の仮戻し処理を実施した。Table 2 に平行部 径 $8 \mathrm{~mm}$, ゲージ長 $56 \mathrm{~mm}$ で引張試験を行ったときの特性 を示す。この供試材をV14鋼とする。

Fig.3に水素脆化試験片形状を示す。試験片形状は高力 ボルトのねじ部の応力集中を模擬した直径 $8 \mathrm{~mm}$, 切欠き 底半径 $6 \mathrm{~mm}$ (切欠き深さ $1 \mathrm{~mm}$ ), 切欠き底の曲率半径 0.12 $\mathrm{mm}$, 応力集中係数は約 5 の環状切欠丸棒試験片を用いた。

\section{$2 \cdot 2$ 水素脆化感受性評価法}

本研究では, 定荷重試験, SSRT, CSRTの3 種の手法を用 いて水素脆化感受性を評価した。

\section{$2 \cdot 2 \cdot 1$ 定荷重試験}

定荷重試験は水素をチャージした試験片に一定応力を 負荷して保持し, 破断応力と水素量の関係を調査する試 験法である。本研究では，高濃度の水素を導入する条件に ついては新日鐵住金 (NSSMC) で実施し，水素チャージ は陰極電解法を用いた。一方，低濃度の水素を導入する条 件については高周波熱錬 (NC) で実施し, FIP (Fédération Internationale de la Précontrainte ) 試験 ${ }^{18,19)}$ に使用されるチ オシアン酸アンモニウム $\left(\mathrm{NH}_{4} \mathrm{SCN}\right)$ 水溶液による浸漬法 ${ }^{9)}$ を用いた。

Table 1. Chemical composition of steels used.

\begin{tabular}{|c|c|c|c|c|c|c|c|c|c|c|}
\hline Steels & $\mathrm{C}$ & $\mathrm{Si}$ & $\mathrm{Mn}$ & $\mathrm{P}$ & $\mathrm{S}$ & $\mathrm{Al}$ & $\mathrm{Cr}$ & Mo & V & $\mathrm{N}$ \\
\hline SCM435 & 0.35 & 0.24 & 0.79 & 0.023 & 0.016 & 0.036 & 1.09 & 0.15 & - & 0.005 \\
\hline V steel & 0.41 & 0.20 & 0.70 & 0.005 & 0.005 & 0.035 & 1.19 & 0.65 & 0.30 & 0.004 \\
\hline
\end{tabular}

Table 2. Mechanical properties of steels used. Specimen dimension SCM435 G.L.: $100 \mathrm{~mm}$, Diameter: $10 \mathrm{~mm}$ V steel G.L.: $56 \mathrm{~mm}$, Diameter: $8 \mathrm{~mm}$

\begin{tabular}{c|c|c|c|c}
\hline Steels & YS / MPa & TS / MPa & El. (\%) & R. A. (\%) \\
\hline SCM435 (S11) & 1003 & 1103 & 12 & 33 \\
V steel (V14) & 1339 & 1443 & 15 & 60 \\
\hline
\end{tabular}

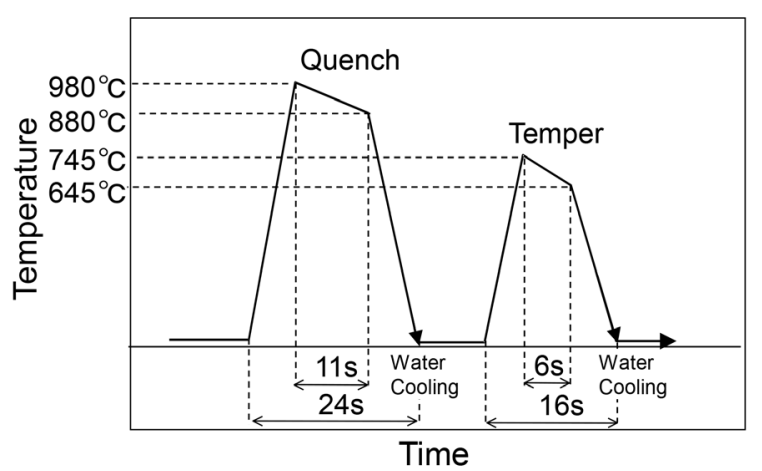

Fig. 1. Schematic diagram of heat treatment condition of SCM435.

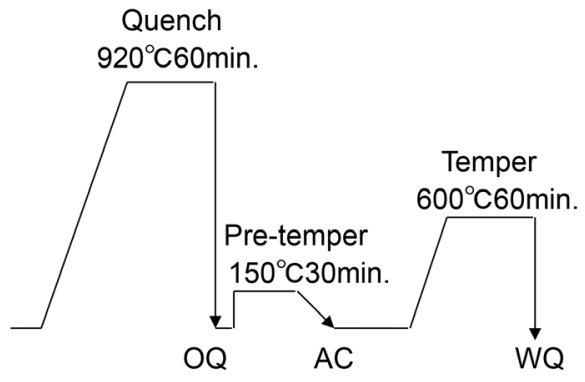

Fig. 2. Schematic diagram of heat treatment condition of V steel.
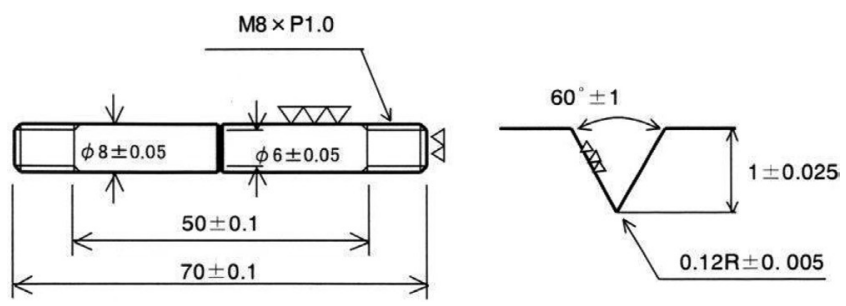

Fig. 3. Specimen dimension. 
陰極電解法による水素チャージは, 3 mass $\% \mathrm{NaCl}+(0.1$ 〜 $20 \mathrm{~g} / \mathrm{L}) \mathrm{NH}_{4} \mathrm{SCN}$ 水溶液で $18 \mathrm{~h}$ の水素チャージを行い, 電 流密度と $\mathrm{NH}_{4} \mathrm{SCN}$ 濃度を変化させることにより，水素量を 変化させた。水素チャージ後に試験片にZnめっきを行い 水素の逃散を防止し, S11鋼については $3 \mathrm{~h}, \mathrm{~V} 14$ 鋼につい ては96 h 室温で放置し，試験片内部の水素を均一化した。 試験片中の水素量は, 試験終了後, 試験片の $\mathrm{Zn}$ めっを除 去後に測定した。

一方, $\mathrm{NH}_{4} \mathrm{SCN}$ 水溶液浸漬による水素チャージは, 溶液 濃度を 0.25 ～ $20 \mathrm{mass} \%$ に調整することにより水素量を変 化させた。試験片に荷重を負荷した後，50 ${ }^{\circ} \mathrm{C}$ 加熱した $\mathrm{NH}_{4} \mathrm{SCN}$ 水溶液を容器内に注入し試験を開始した。容器は Fig.4に示すような2重構造となっており, $\mathrm{NH}_{4} \mathrm{SCN}$ 水溶液 の周囲に温水を循環させて水溶液温度が $50{ }^{\circ} \mathrm{C}$ となるよう に保持した。本手法では，荷重を負荷後に水素チャージを 開始するため, 試験中に水素量が増加する。このため, 予 備試験として 11 鋼およびV14鋼を用いて 1 mass \% および 20 mass $\% \mathrm{NH}_{4} \mathrm{SCN}$ 水溶液中に無負荷で浸漬した際の浸漬 時間と拡散性水素量の関係を調査した。浸漬によって水素 チャージされた試験片中の拡散性水素量は，所定の時間浸 漬後エメリー紙\#1000を用いて表層の腐食生成物を研磨除 去した後に測定した。

定荷重試験は，水素チャージを行わない環状切欠丸棒 試験片の最大引張応力を基準として負荷応力を設定した。 $\mathrm{S} 11$ 鋼は環状切欠丸棒試験片の最大引張応力 $1663 \mathrm{MPa}$ に 対 し, $1497 \mathrm{MPa}$ (0.9倍)，1330 MPa (0.8倍), $993 \mathrm{MPa}(0.6$ 倍) の応力を，V14鋼は，最大引張応力 $2023 \mathrm{MPa}$ に対し， $1618 \mathrm{MPa}$ (0.8倍), $1299 \mathrm{MPa}$ (0.6倍) の応力を負荷して定 荷重試験を行った。環状切欠丸棒試験片の最大引張応力 $\sigma$ $\left[\mathrm{N} / \mathrm{mm}^{2}=\mathrm{MPa}\right]$ は最大引張荷重 $\mathrm{P}[\mathrm{N}]$ および切欠き部の 断面積 $\left(\Phi 6.0 \mathrm{~mm}: 28.3 \mathrm{~mm}^{2}\right)$ を用いて, 式 (1) から算出 した。

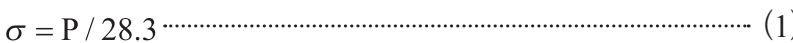

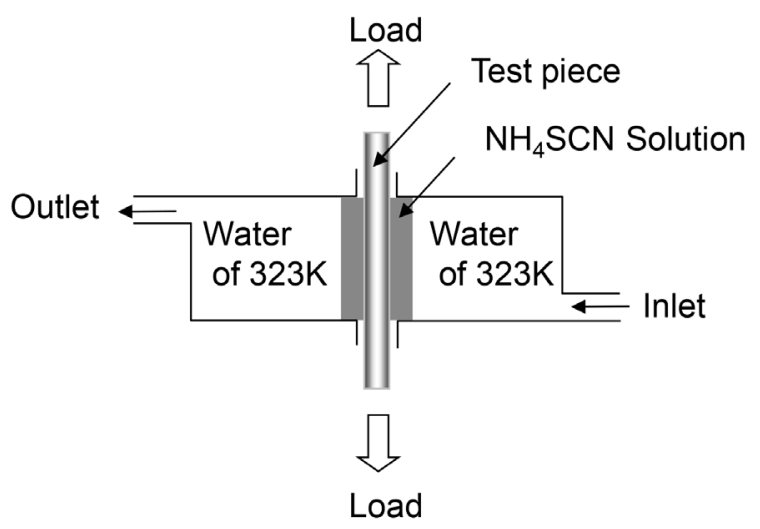

Fig. 4. Schematic illustration of test cell for immersion in $\mathrm{NH}_{4} \mathrm{SCN}$ solution.
負荷を開始して $100 \mathrm{~h}$ 経過後未破断の場合は試験を打ち 切った。試験片中の拡散性水素量は, 各濃度の溶液に無負 荷で $100 \mathrm{~h}$ 浸漬後に上記と同様にエメリー紙\#1000を用い て表層の腐食生成物を研磨除去した試料の測定值を用い た。

水素は昇温脱離法にて，ガスクロマトグラフにより測定 した。

\section{$2 \cdot 2 \cdot 2$ SSRT}

水素をチャージした試験片のSSRT（Slow Strain Rate Technique, 低ひずみ速度引張試験) ${ }^{6-12)}$ を行い, 水素量と破 断応力の関係から水素脆化感受性の評価を行った。試験片 には環状切欠丸棒試験片を用いたため，切欠き部での㛜密 なひずみ速度は定義できず, 低速引張試験と呼称する方が 正しいが，一般に低変位速度での引張試験が SSRT と呼ば れることから，ここではSSRTの呼称を用いる。低速で試 験を行う理由は, 試験中に水素の応力誘起拡散に要する時 間を与え，試験片内の応力分布に対応した水素濃度分布を 得るためである。水素チャージ試験片のSSRTによって， 比較的広い水素量範囲での破断応力の変化が得られ, 水素 脆化感受性を評価することが可能である。この方法で求め た破断応力と水素量の関係は，定荷重試験（CLT）によっ て求めた負荷応力と限界拡散性水素量の関係と一致するこ とが期待される。

SSRTにより, S11鋼およびV14鋼について水素脆化特性 評価を行った。SSRTは新日鐵住金 (NSSMC) および物質・ 材料研究機構 (NIMS) で試験を行った。

試験片へは陰極電解法により水素を導入した。NSSMC では3 mass\% $\mathrm{NaCl}+(0 \sim 3 \mathrm{~g} / \mathrm{L}) \mathrm{NH}_{4} \mathrm{SCN}$ 水溶液を用い電 流密度 0.3-2.0 A $/ \mathrm{m}^{2}$ で $18 \mathrm{~h}$ 水素チャージを行い, NIMS で は3 $\mathrm{mass} \% \mathrm{NaCl}+3 \mathrm{~g} / \mathrm{L} \mathrm{NH}_{4} \mathrm{SCN}$ 水溶液もしくは $0.1 \mathrm{~mol} / \mathrm{L}$ $\mathrm{NaOH}$ 水溶液を用い電流密度0.4-6.25 A/m² 72 h 水素 チャージを行った。それぞれ溶液と電流密度を変化させる ことにより水素量を変化させた。水素をチャージした試験 片にはNSSMCではZnめっきを, NIMSではCdめっきを施 し, SSRT中の水素の逃散を防止した。めっき後, NSSMC では, $\mathrm{S} 11$ 鋼については $3 \mathrm{~h}, \mathrm{~V} 14$ 鋼については $96 \mathrm{~h}$ 室温で 放置し，試験片内部の水素を均一化した。一方，NIMSで は，水素チャージ時間を $72 \mathrm{~h}$ と長くすることでチャージ中 に水素を均一化させると考え, 放置せずにSSRTを実施し た。

SSRT $0.005 \mathrm{~mm} / \mathrm{min}$ のクロスヘッド変位速度で行っ た。試験後に, NSSMCではガスクロマトグラフを, NIMS では四重極質量分析器を水素検出に用いた分析装置を使 い，昇温脱離法により水素分析を行った。

\section{$2 \cdot 2 \cdot 3$ CSRT}

水素脆化評価法として SSRTが水素の応力誘起拡散を 時々刻々，平衡状態にまで起こさせるために時間をかける 極低ひずみ速度で行うのに対し，逆に $\mathrm{CSRT}^{13-16)}$ は水素の 
応力誘起拡散が無視できる程度のひずみ速度, すなわち通 常の引張試験速度で行う。そのためにCSRTでは水素脆化 割机起点の水素量を試験片の平均水素量で表現することか ら，あらかじめ試験片に飽和するまで均一に水素をチャー ジする。その場合, 供試鋼に応じて飽和までの水素チャー ジ時間を決定することになる。

S11鋼およびV14鋼について環状切欠丸棒試験片を用 いたCSRTによって複数の研究機関で水素脆化特性を検 討した。S11鋼のCSRTは上智大学 (SPU), 新日鐵住金 $(\mathrm{NSSMC})$, 三菱製鋼 $(\mathrm{MSM})$ で，また, V14鋼のCSRTは上 智大学 (SPU), 新日鐵住金 (NSSMC), 物質 - 材料研究機 構（NIMS）で行った。環状切欠丸棒試験片のねじ部をシリ コン樹脂でコーティングした上で切欠きをはさんで20〜 $40 \mathrm{~mm}$ に陰極電解法で水素をチャージした。電解液として 3 mass $\% \mathrm{NaCl}+0 \sim 3 \mathrm{~g} / \mathrm{L} \mathrm{NH}_{4} \mathrm{SCN}$ もしくは $0.1 \mathrm{~mol} / \mathrm{L}-\mathrm{NaOH}$ を用い，電流密度を $0.25 \sim 80 \mathrm{~A} / \mathrm{m}^{2}$ に変化させることで広 範囲の水素量をチャージした。今回用いた環状切欠丸棒試 験片に水素が飽和するまでのチャージ時間は $\mathrm{S} 11$ 鋼で $72 \mathrm{~h}$ 程度, $\mathrm{V} 14$ 鋼で $120 \mathrm{~h}$ 程度であった。それぞれの機関での水 素チャージ時間は, S11においてSPUは72〜144 h, NSSMC は144h，MSMは72 hで，V14鋼においてSPUは $120 \mathrm{~h}$, NSSMCは144h，NIMSは336hであった。

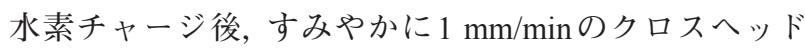
変位速度でCSRTの引張試験を行った。試験後, 破断面部 を切り出し, ガスクロマトグラフを用いて昇温脱離法によ り水素分析を行った。また, 破面はSEMにより破壊形態を 明らかにした。

\section{$2 \cdot 3$ 水素分析方法}

試験片中の拡散性水素量は, ガスクロマトグラフィーも しくは質量分析計を用いた昇温脱離分析法により求めた。 昇温速度は $100{ }^{\circ} \mathrm{C} / \mathrm{h}$ とし, $300{ }^{\circ} \mathrm{C}$ 以下の第一ピーク終了ま でに放出された水素の合計を拡散性水素量とした。

\section{3. 結果}

\section{$3 \cdot 1$ 水素吸蔵挙動}

陰極電解法でチャージした水素の昇温脱離分析の結果, $\mathrm{S} 11$ 鋼では水素放出曲線のピーク温度は $100{ }^{\circ} \mathrm{C}$ 近傍にあ り, 同種のSCM鋼材で引張強さ $1300 \mathrm{MPa}$ および $1500 \mathrm{MPa}$ について得られたもの ${ }^{13,14)}$ と同等であった。一方, V14鋼 については, Fig.5に示すように水素放出曲線のピーク温度 は, 水素量が少ない場合には約 $150{ }^{\circ} \mathrm{C}$, 水素量が多い場合

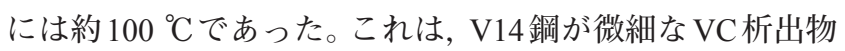
など水素トラップエネルギーの大きいトラップサイトを有 しているためで，チャージされた水素はまずは強いトラッ プサイトに入り, 水素量の増大に伴って順次弱いトラップ サイトに吸蔵されること ${ }^{3)}$ で理解される。

\section{$3 \cdot 2$ 定荷重試験}

$\mathrm{NH}_{4} \mathrm{SCN}$ 水溶液浸漬による水素チャージの予備試験とし て 1 mass\% 打よび 20 mass $\% \mathrm{NH}_{4} \mathrm{SCN}$ 水溶液中に無負荷て 浸漬した際の浸漬時間と拡散性水素量の関係を調查した。 その結果をFig.6に示す。S11鋼では, いずれの濃度におい ても拡散性水素量は $20 \mathrm{~h}$ までは増加し, その後は一定の值

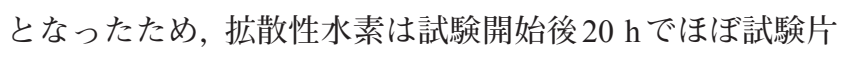
内で均一化すると考えられる。一方, V14鋼では浸漬時間 の増加に伴い拡散性水素量は増加していたため, 試験中に も水素量は増加していると考える必要がある。

Fig.7にS11鋼扎よびV14鋼の拡散性水素量一破断時間曲 線の一例を示す。いずれの鋼種に打いても，拡散性水素量 が減少するにともない破断時間が長くなっており, 他の応 力水準に打いても同様の傾向を示した。応力条件と材料に 依存して, 所定の水素量以下では $100 \mathrm{~h} て ゙ も$ 破断が起こら なかった。

Fig.8にS11鋼およびV14鋼の負荷応力と拡散性水素量 の関係を示す。罒中の白抜きマークは破断した試験片で測

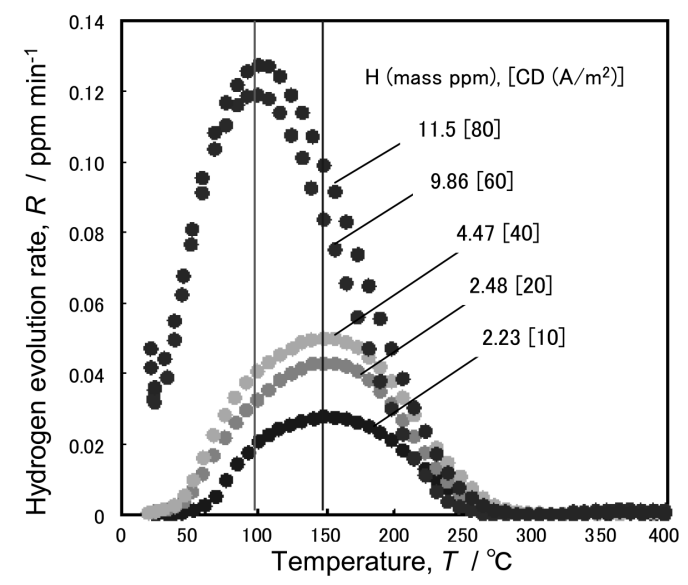

Fig.5. Hydrogen curves of various hydrogen content for steel V14 charged in aqueous solutions of $0.1 \mathrm{M} \mathrm{NaOH}$ at current densities (CD) in the range from 10 to $80 \mathrm{~A} / \mathrm{m}^{2}$.

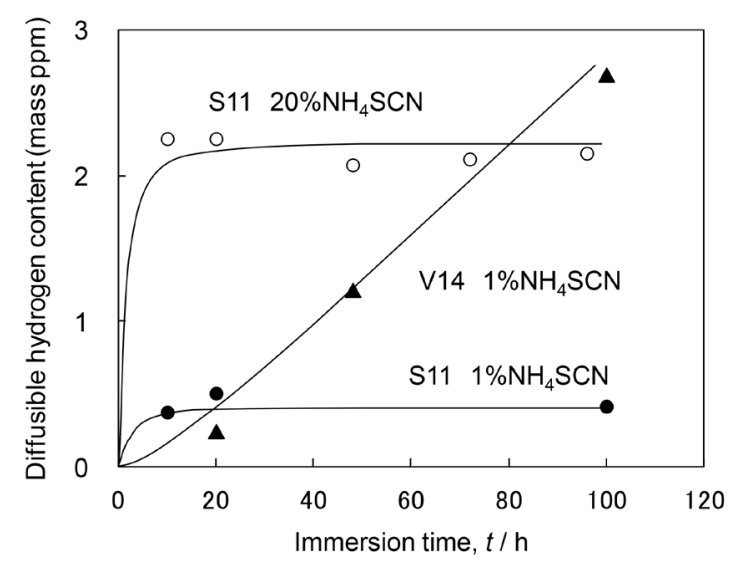

Fig. 6. Relationship between immersion time in $\mathrm{NH}_{4} \mathrm{SCN}$ solution and diffusible hydrogen content for steel S11 and steel V14. (without load) 

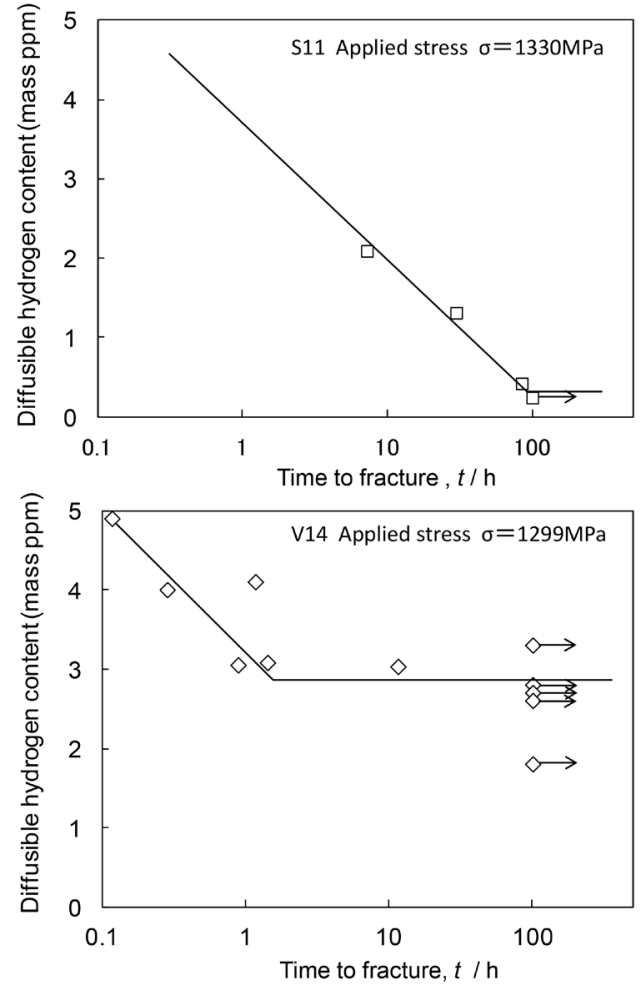

Fig. 7. Examples of relationship between time to fracture and diffusible hydrogen content for steel S11 (immersion in $\mathrm{NH}_{4} \mathrm{SCN}$ ) and steel V14 (cathodic hydrogen charging).
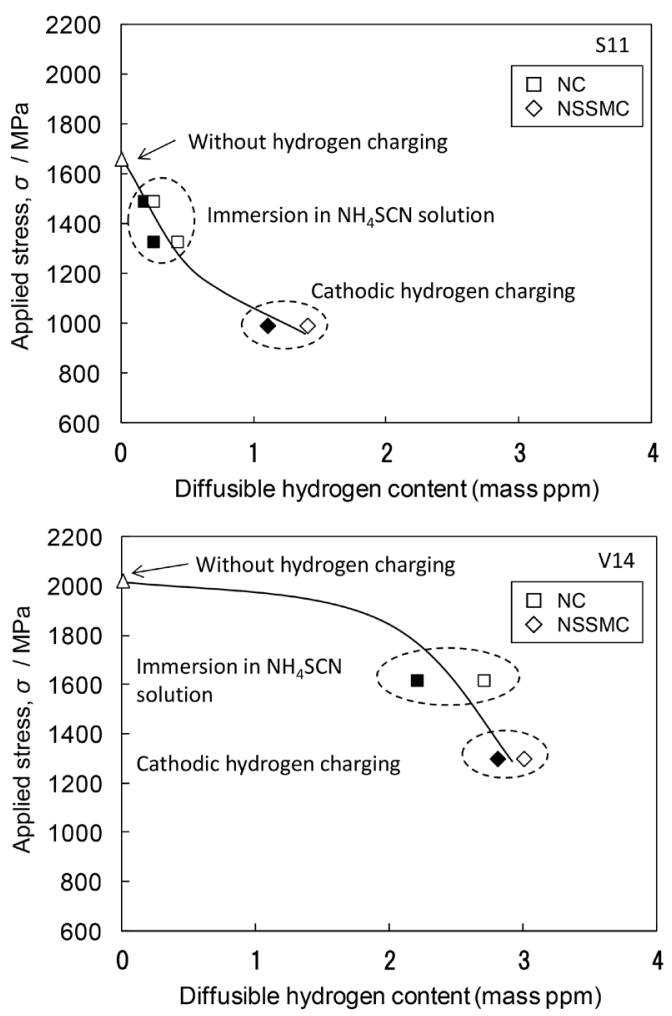

Fig. 8. Relationship between applied stress and critical diffusible hydrogen content under constant load for steel S11 and steel V14 (solid : no fracture, open : fracture). The experiments were carried out in Neturen Co., Ltd. (NC, immersion in $\mathrm{NH}_{4} \mathrm{SCN}$ ) and Nippon Steel \& Sumitomo Metal Corp. (NSSMC, cathodic hydrogen charging).
定された水素量の最小值，図中の黒塗りマークは破断しな かった試験片で測定された水素量の最大值（ただし白抜き マークよりも低い水素量の試験片)，を示す。参考のため, 環状切欠丸棒試験片に水素をチャージせずに引張試験を 行った際の引張強さも併記している。いずれの鋼種におい ても，拡散性水素量が増加するほど破断応力が低下する傾 向を示している。同一の水素量を基準にして比較すると， $\mathrm{V} 14$ 鋼の破断応力はS11鋼より高い值であった。また，負 荷応力と拡散性水素量の限界線は, 浸漬法と陰極チャージ 法で同じ線上に位置した。

\section{$3 \cdot 3$ SSRT}

SSRTで求めた切欠き断面部の公称破壊応力と昇温脱離 法によって求めた試験片内の平均的な水素量の関係を, S11鋼およびV14鋼についてそれぞれFig.9 と Fig.10に示 す。いずれの鋼種も, 水素量の増加に伴い破断応力は低下 した。S11の破壞応力と水素量の関係は, 2機関とも同様の 傾向を示した。NIMSで行ったSSRTでの破面の割机発生起 点周辺では, 約 0.5 mass ppmの水素量を境に, 低水素濃度 側で擬へき開 (Quasi-cleavage, 以降 QC)，高水素濃度で擬 へき開に旧オーステナイト $(\gamma)$ 粒界割れ（Inter-granular,

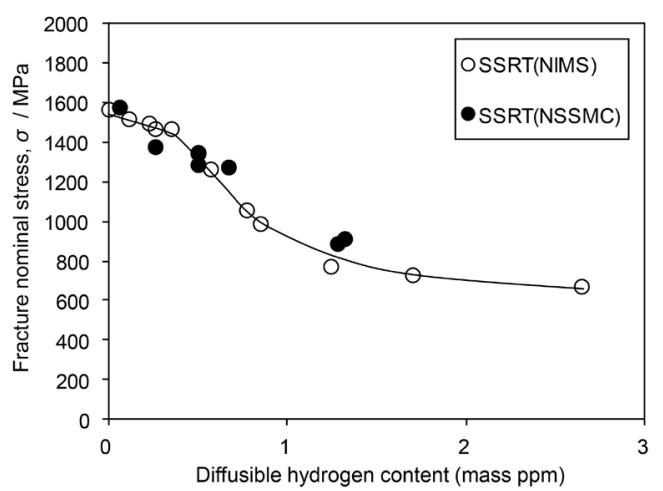

Fig. 9. Relationship between fracture nominal stress and diffusible hydrogen content obtained by SSRT for steel S11. The experiments were carried out in National Institute for Materials Science (NIMS) and NSSMC.

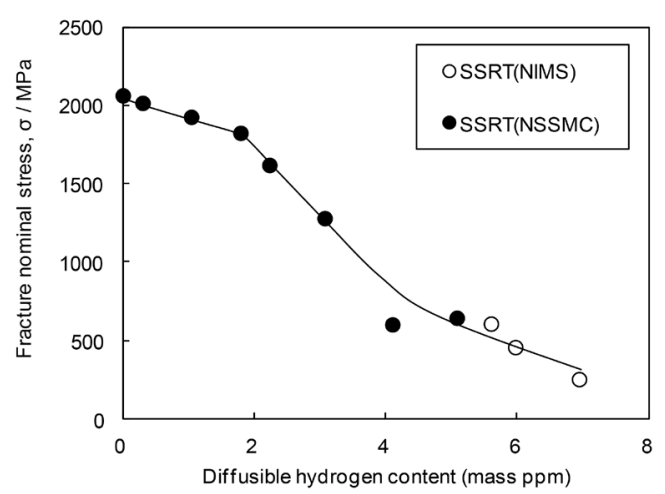

Fig. 10. Relationship between fracture nominal stress and diffusible hydrogen content obtained by SSRT for steel V14. The experiments were carried out in NIMS and NSSMC. 
以降IG）が混在した破面形態が見られた。公称破壊応力の 低下は低水素濃度側で比較的緩やかで, 高水素濃度側でよ り著しかった。この傾向は, S11鋼と同等の引張強さのボ ロン添加焼戻しマルテンサイト鋼のSSRT の結果 ${ }^{7)}$ と同様 である。破面観察の結果と合わせると, IGが発生すると破 壊応力が急激に低下寸ると考えられる。

$\mathrm{V} 14$ 鋼の場合, 微細に析出したVCが水素トラップとし て働くため，同等の水素チャージ条件での水素量は S11 鋼 よりも著しく高くなる。一般的に，引張強さが高い材料は 低い材料と比較して, 水素チャージした際の公称破壊応力 の低下量が大きくなるのに対し，同一水素量を基準にして 比較すると V14 鋼の公称破壊応力は $\mathrm{S} 11$ 鋼のそれより明ら かに高かった。

\section{$3 \cdot 4$ CSRT}

CSRTによる水素脆化特性評価として切欠き断面部の公 称破壊応力と水素量 $\left(\mathrm{CSRT}\right.$ での平均水素量 $\mathrm{H}_{\mathrm{CSRT}}=$ 破壊起 点の水素量 $\left.H^{*}\right)$ の関係を $\mathrm{S} 11$ 鋼打よびV14鋼についてそれ ぞれFig.11 およびFig.12に示す。それぞれの鋼材で3つの機 関で実験したが，ほぼ同等な公称破壞応力と水素量の関係 が得られ, CSRTが変動要因の少ない試験法であることが

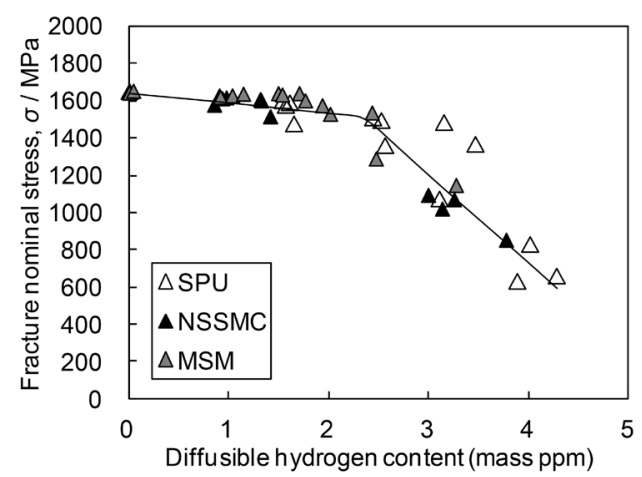

Fig. 11. Relationship between fracture nominal stress and diffusible hydrogen content obtained by CSRT for steel S11. The experiments were carried out in Sophia University (SPU), Mitsubishi Steel Mfg. Co., Ltd. (MSM) and NSSMC.

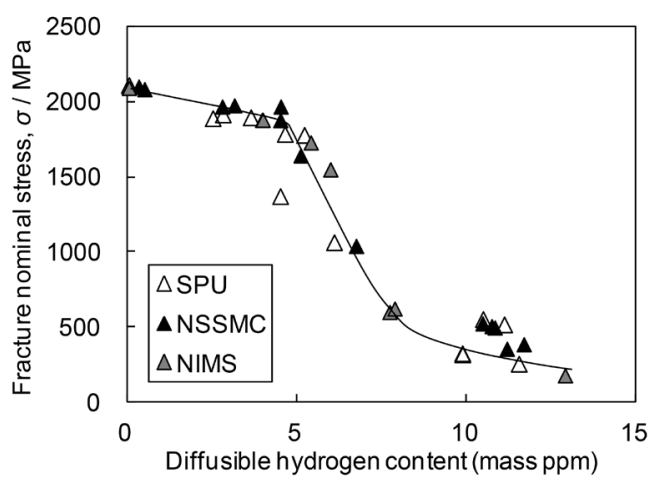

Fig. 12. Relationship between fracture nominal stress and diffusible hydrogen content obtained by CSRT for steel V14. The experiments were carried out in SPU, NIMS and NSSMC.
示されている。また，同一の水素量で比較するとS11よりも V14の方が高い破断応力を示した。公称破壞応力と水素量 の関係は, S11鋼の場合には水素量が $2.5 〜 3.0$ mass ppmを 境に，また，V14鋼の場合は約 5 mass ppmを境に2つの関係 となっている。すなわち, 水素量が少ない領域では水素量 の増大に伴って破壊応力は徐々に低下寸るが, 水素量が多 い領域になると水素量の増大に伴って破壞応力は著しく低 下している。この破壊応力の急な低下は破面観察結果の変 化と対応していた。水素量の少ない領域では, 破壊起点と なる切欠き先端から数 $10 \mu \mathrm{m}$ 内側に入ったところでQCが主 体となって打り, 水素量の多い領域の結果ではIGが混在す るようになり，破壊形態の水素量依存性を持つことがわか る。IGの方が破断応力の低下が大きく水素脆化感受性が高 いことを示しており，SSRTの結果と同様の傾向を示した。

\section{4. 考察}

定荷重試験 (CLT), SSRT およびCSRTで求めたS11鋼お よびV14鋼の水素脆化特性, すなわち拡散性水素量と切欠 き断面部の公称破壊応力の関係をそれぞれFig.13，Fig.14

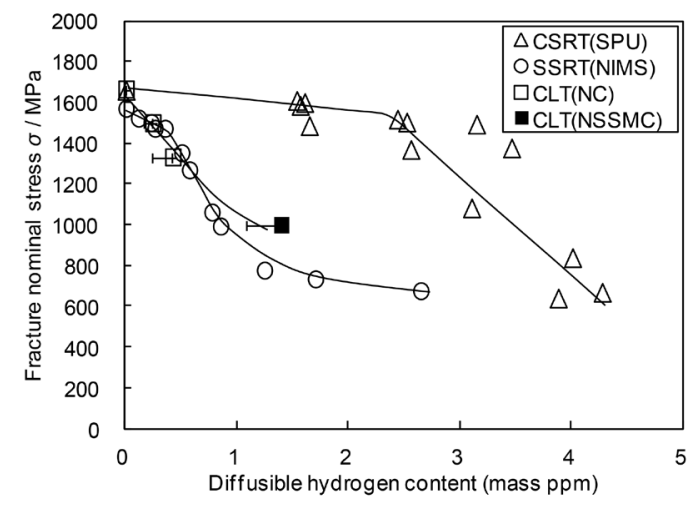

Fig. 13. Comparison among the hydrogen embrittlement resistance obtained by CLT, SSRT and CSRT for steel S11.

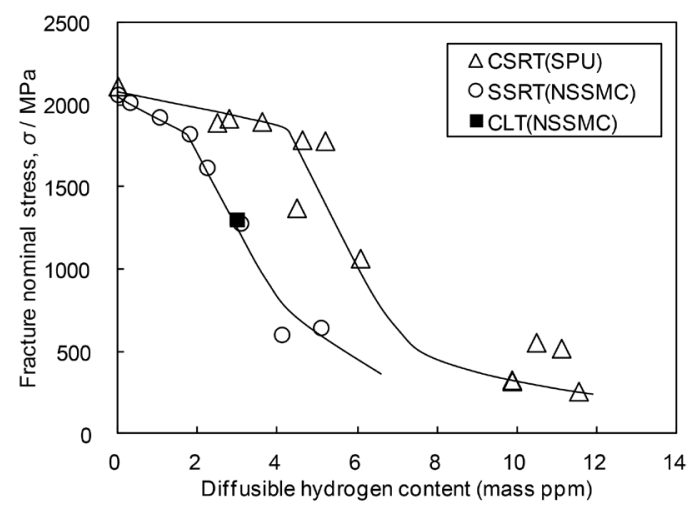

Fig. 14. Comparison among the hydrogen embrittlement resistance obtained by CLT, SSRT and CSRT for steel V14. 
に示す。定荷重試験では, 破壊した最も少ない水素量の結 果をプロットし，破壊しなかった最も多い水素量の結果を 誤差範囲にて表記した。CSRT は水素の応力誘起拡散が生 じない短時間で評価する方法であるため，同じ破壊応力レ ベルで比較すると他の試験方法より多くの水素量を含有し ている。一方，定荷重試験と SSRT は破壊応力と水素量の 関係がほぼ同程度である。この理由は，どちらの試験法も 応力誘起拡散が生じる十分な試験時間を有することから， 試験中に試験片内の応力分布に応じた水素濃度分布が生 じ，破壊に至るプロセスが近いためと推定される。

また, SSRTとCSRTの拡散性水素量と破壊応力の関係 は，両試験法ともに破面形態に応じて変化する。低水素量 領域ではQCが主体で拡散性水素量の増加に対して破壊応 力が徐々に低下するのに対し，ある水素量を超えると IG が混在し破壊応力が急激に低下する。

Hagihara ${ }^{13,14)}$ は1300〜1500 MPa級鋼を用いて SSRT と CSRTの水素脆化限界の比較を行い，拡散性水素の応力集 中部への集積を考慮したときに水素脆化挙動が SSRTと CSRTでほぼ同じであり，水素脆化限界は破壊起点での局 所的な応力と拡散性水素量で決定されると報告している。 そこで，同様の手法を用いて本研究における応力誘起拡散 により集積した局所拡散性水素量 $H^{*}$ を(2) 式 ${ }^{6)}$ を用いて 推定し, 定荷重試験, SSRT とCSRTの試験法で得られた水 素脆化限界を比較した。

$$
H^{*}=H \times \exp \left\{\frac{\left(-\left(\sigma_{\mathrm{h}}-\sigma_{\mathrm{h} \min }\right) \times \Delta V\right)}{R T}\right\}
$$

ここで, $H$ は昇温脱離分析により求められた試験片中 の平均拡散性水素量, $\sigma_{\mathrm{h}}$ は応力集中部での静水圧応力, $\sigma_{\mathrm{hmin}}$ は試験片中の切欠き底から十分離れた位置での静水 圧応力， $\Delta V$ はbcc Fe中の水素の部分モル体積で $2 \times 10^{-6}$

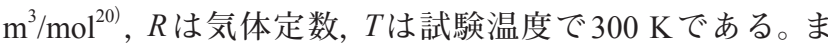
た， $\sigma_{\mathrm{h}}$ は弾塑性解析によって求めた。解析条件は，Marcを 用いて 2 次元の軸対称モデルとし, TS 以下の領域の応力と 歪みの関係は平滑試験片の引張試験結果を用い, TSを超 える領域の歪みと応力の関係はn乗硬化則で推定した。

Fig.15，Fig.16に定荷重試験, SSRTでの破壊起点の局所 拡散性水素量を式 (2) を用いて求め, CSRTの破壊限界と 比較した結果を示す。縦軸は，破壊起点での局所応力では なく試験片の最小断面積部での平均破壊応力であるが，本 検討では試験片形状がいずれの試験においても同一である ため，平均破壊応力と応力が最大となる局所応力は一対一 の対応関係にある。局所的に集積した拡散性水素を考慮し て $1100 \mathrm{MPa}$ 級のS11鋼の水素脆化特性を評価すると, 破断 する水素量の序列は SSRT < CLT < CSRT となった。一方， $1400 \mathrm{MPa}$ 級のV14鋼では，破断する水素量の序列はCSRT $<\mathrm{CLT} \fallingdotseq \mathrm{SSRT}$ であった。
以上の結果は, 従来の Hagihara らの実験結果 ${ }^{13)}$ と異なっ ている。その理由として，S11鋼に関しては実験に用いた 鋼材強度の差異が考えられる。Hagiharaらは引張強さが $1300 \mathrm{MPa}$ 級の材料を用い，主に IG を生じているのに対し， 本実験では引張強さが $1100 \mathrm{MPa}$ 級で QCが主体となって いる。つまり，引張強さが $1100 \mathrm{MPa}$ 級鋼は，1300 MPa級 鋼よりも破壊の際に塑性変形の寄与が大きいと考えられ る。Takai $~^{21)}$ は, 水素と転位の相互作用により水素脆化 が促進すると報告している。SSRT は転位が低速で移動す るため, 転位に引きずられる形で水素が拡散し, 転位と水 素の相互作用が大きいと推定される。それに対し, CSRT は転位が高速で移動するため, 水素は転位の移動に連動で きず，転位と水素の相互作用が小さいと推定される。した がって, 局所的に同じ水素量でも SSRTより CSRTは水素 脆化感受性が小さくなる可能性が考えられる。一方, 定荷 重試験は応力負荷時に急激に転位が移動するため水素と転 位の相互作用は小さいと思われるが，試験中のリラクゼー ションによって転位が若干移動するため, 水素脆化感受性 はSSRTとCSRTの間になったと推定される。

水素トラップ鋼のV14に関しては，(2) 式の適用の妥当

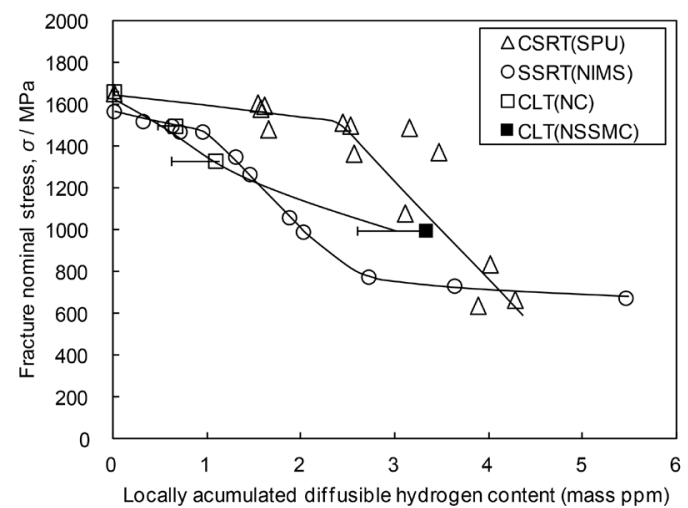

Fig. 15. Comparison among the hydrogen embrittlement resistance based on locally accumulated hydrogen obtained by CLT, SSRT and CSRT for steel S11.

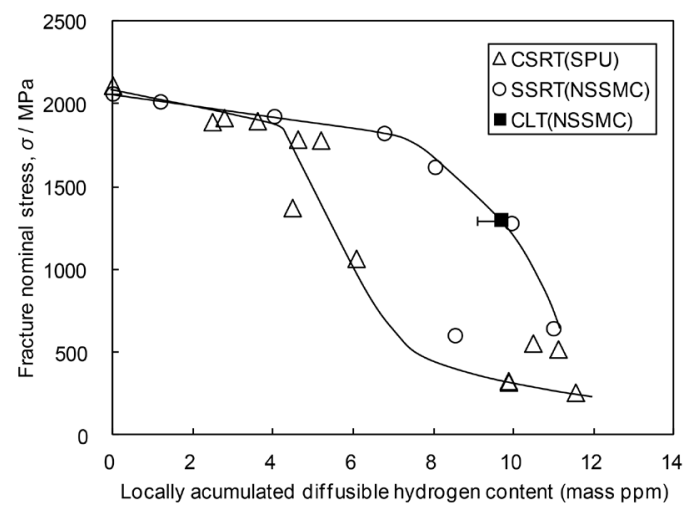

Fig. 16. Comparison among the hydrogen embrittlement resistance based on locally accumulated hydrogen obtained by CLT, SSRT and CSRT for steel V14. 
性も検討する必要があると考えられる。CSRTは他2つの 試験法の局所拡散性水素量と同等の水素量を均一に添加 する試験方法であるため, 評価する際は実部品の応力集中 度から局所に集中する水素量を計算する必要がある。しか し,トラップサイトのある鋼種に（2）式を適用する妥当性 は確認できていない。そのため, 主に拡散性水素がV炭化 物にトラップされているV添加鋼において，(2) 式によっ て局所拡散性水素量を計算して求めた值は, 破壊発生時に 実際に集積した局所水素量と大きく異なっている可能性が 考えられる。

\section{5. 結言}

定荷重試験, SSRT, CSRTにて水素脆化に打ける水素脆 化感受性を SCM435（S11鋼）およびV添加鋼（V14鋼）に ついてラウンドロビンテストを行った結果, 以下の知見が 得られた。

（1）定荷重試験は2機関で実施され，チオシアン酸アンモ ニゥム $\left(\mathrm{NH}_{4} \mathrm{SCN}\right)$ 水溶液浸漬と陰極電解による異なる 水素チャージ方法を用いても, 水素量の増加に伴い破 断応力が低下する傾向を示し, 大きなばらつきは見ら れなかった。

(2) SSRT試験は2機関で実施され，拡散性水素量と公称破 壞応力の関係は2機関ともに同様の結果が得られた。 また, S11鋼では 0.5 mass ppmより低水素量側でQC破 壞 (Quasi-cleavage, 擬へき開), 高水素量側でIG 破壞 (Inter-granular, 粒界) であり, IG 破面を示す領域では 拡散性水素量に対する公称破壞応力の低下が顕著で あった。

(3) CSRT試験は，それぞれの鋼材において3機関で実施 され，拡散性水素量と公称破壊応力の関係はいずれも 同等の関係が得られた。また, S11鋼では 2.5 3.0 mass $\mathrm{ppm}$ を境に, V14鋼では 5 mass ppmを境にSSRT と同 様な拡散性水素量に対する公称破壊応力の低下を示し た。

（4）いずれの試験法においても，V14鋼はS11鋼と比較し て同等の水素チャージ条件で拡散性水素量は増加し た。また, 同じ拡散性水素量で比較するとV14鋼の公 称破壊応力はS11鋼より高かった。

（5）定荷重試験, SSRT, CSRTの3つの試験方法を比較する と, 定荷重試験とSSRT は水素の拡散を考虑した試験法
であるため, 拡散性水素量と公称破壊応力について同 等の関係が得られる。また, 静水圧応力場による水素 の拡散，集中を考慮して局所拡散性水素量を計算する と, 同じ公称破壞応力で比較した際に局所拡散性水素 量はS11鋼でSSRT <CLT < CSRTの関係となった。一 方，V14鋼ではCSRT $<$ CLT $\fallingdotseq \mathrm{SSRT}$ の関係となった。 S11鋼に関して, 局所的に同じ水素量でもSSRTより CSRTは水素脆化感受性が小さくなった理由は, SSRT は転位が低速で移動するため転位と水素の相互作用が 大きいのに対し, CSRTは転位が高速で移動するため 転位と水素の相互作用が小さいためであると推定され る。

\section{文献}

1 ) S.Matsuyama: Delayed Fracture, The Nikkan Kogyo Shimbun, Ltd., Tokyo, (1989), 25.

2 ) A.R.Troiano: Trans. Am. Soc. Met., 52 (1960), 54.

3 ) S.Yamasaki and T.Takahashi: Tetsu-to-Hagané, 83 (1997), 454.

4 ) S.Yamasaki, M.Kubota and T.Tarui: Nippon Steel Technical Rep., 80 (1999), 50.

5 ) T.Kushida, H.Matsumoto, N.Kuratomi, T.Tsumura, F.Nakasato and T.Kudo: Tetsu-to-Hagané, 82 (1996), 297.

6 ) M.Q.Wang, E.Akiyama and K.Tsuzaki: Mater. Sci. Eng., $\mathbf{A 3 9 8}$ (2005), 37.

7 ) M.Q.Wang, E.Akiyama and K.Tsuzaki: Corros. Sci., 49 (2007), 4081.

8 ) M.Q.Wang, E.Akiyama and K.Tsuzaki: Mater. Sci. Technol., 22 (2006), 167.

9 ) M.Q.Wang, E.Akiyama and K.Tsuzaki: Scr. Mater, 52 (2005), 403.

10) M.Q.Wang, E.Akiyama and K.Tsuzaki: Scr. Mater, 53 (2005), 713.

11) D.G.Enos and J.R.Scully: Metall. Mater. Trans. A, 33A (2002) 1151.

12) W.Urushihara, F.Yuse, T.Nakayama, Y.Namimura and N.Ibaraki: Kobe Steel Eng. Rep., 52 (2002) 57.

13) Y.Hagihara, C.Ito, N.Hisamori, H.Suzuki, K.Takai and E.Akiyama: Tetsu-to-Hagané, 94 (2008), 215.

14) Y.Hagihara, C.Ito, D.Kirikae, N.Hisamori, H.Suzuki and K.Takai: Tetsu-to-Hagané, 95 (2009), 489.

15) Y.Hagihara: ISIJ Int., 52 (2012), 292.

16) Y.Hagihara, T.Shobu, N.Hisamori, H.Suzuki, K.Takai and K.Hirai: ISIJ Int., 52 (2012), 298.

17) T.Hojo, K.Sugimoto, Y.Mukai and S.Ikeda: ISIJ Int., 48 (2008), 824.

18) Fédération Internationale de la Précontrainte: Report on Prestressing Steel: 5. Stress Corrosion Cracking Resistance Test for Prestressing Tendons, 5 (1980).

19) Method of hydrogen embrittlement test for steel for prestressed concrete in a $20 \%$ ammonium thiocyanate solution (JSCE S 1201): Japan Society of Corrosion Engineering, (2012).

20) J.O'M.Bockris, W.Beck, M.A.Genshaw, P.K.Subramanyan and F.S.Williams: Acta Metall., 19 (1971), 1209.

21) K.Takai, H.Shoda, H.Suzuki and M.Nagumo: Acta Mater, 56 (2008), 5158. 